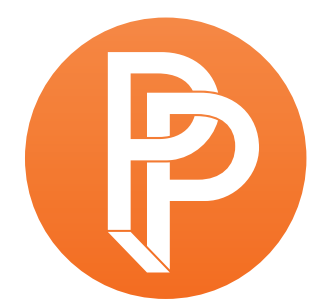

PERFORMANCE

PHILOSOPHY

\title{
ETHICS, GESTURE AND THE WESTERN
}

MICHAEL MINDEN JESUS COLLEGE, UNIVERSITY OF CAMBRIDGE

Hollywood Western films constitute one of the truly unmistakeable genres in the era of cinema. This reality of genre, and the expectations and effects that it enables in real people, demand to be taken seriously when one thinks about how cultures of performance and fiction relate to the challenge to think creatively about ethics. However, the commercial and formulaic nature of the products of Hollywood seem to represent a kind of medial discourse quite antithetical to serious ethical reflection. Giorgio Agamben is in my view exemplary in the creativity of his thinking about ethics. As part of this engagement he is deeply interested in what he calls the ethics of gesture in performance and film. I would like, in what follows, to think about the Western, despite its origins in the sphere of commodities, within an Agambenian framework. At the same time my intention is to exploit the genre's accessibility with a view to probing and clarifying Agamben's sometimes tangled elucubrations. Drawing on David Foster Wallace's reflections on genre structures in his novel Infinite Jest, my conclusion will be that alongside an ethics of gesture, we should also be thinking about an ethics of genre when we reflect upon a possible ethical life today.

\section{The Hollywood Western: An Unlikely Place for an Ethics of Gesture?}

Agamben takes the position that western society of the twentieth century 'lost its gestures' in the sense that pathological forms of the loss of bodily control, 'ataxia, tics, and dystonia', became the norm, and thus invisible and forgotten $(2000,51)$. This is associated for him with the coming to dominance of images-Debord's 'spectacle'-and the fateful subordination of the authenticity of human gesturality, along with the ethical responsibility for how human creatures conduct themselves and their political institutions in the world. Broadly understood, this echoes that 
fundamental deformation opposed by Agamben, namely the line of demarcation between 'bare life', or the breath of existence, and sovereign power-manifest in the radical disconnection between the machinery of the state and those marginalised by modernity, such as camp inmates and refugees, to whom personhood is effectively denied (see Birmingham 2011, 132-3).

In Agamben's view, the medium and technology of cinema can 'lead images back to the homeland of gesture' $(2000,55)$. The example he gives is Samuel Beckett's final piece for television, named after and featuring Schubert's Lied 'Nacht und Träume'. In this ten-minute piece a performer places his head on his hands while his dream of comfort and companionship, forthcoming from disembodied hands appearing out of the surrounding darkness, is shown twice, once in the opposite corner to the dreamer, and once occupying the centre of the screen. Agamben writes: 'According to the beautiful definition implicit in Beckett's Traum und Nacht [sic], [cinema] is the dream of a gesture. The duty of the director is to introduce into this dream the element of awakening' (55).

A recent installation piece by the Danish artist Joachim Koester points to a link between an Agambenian ethics of gesture and the Western movie. ${ }^{1}$ Koester's response to Agamben's challenge to do his directorial duty by introducing the element of awakening into a cinematic traffic of images, is an approximately thirty-minute video, The Place of Dead Roads, shown in a perpetual loop in one of the darkened spaces of the installation. Four cowboys compulsively repeat actions recognizable as motifs from the Western genre (drawing guns, circling menacingly, waiting in ambush etc.). The gestures they make, radically separated from the narrative context from which they derive, seem to arise from deep within their bodies. To quote from the wall-mounted exposition:

\section{Gradually, as the cowboys engage in an exploration of these dark sensations, the jerks and involuntary movements of their actions come to resemble a strange dance. Koester writes about the film [...] 'The "happy dance" [...] can be seen as an attempt to end the spell of historic violence'. (Koester 2017)}

In other words, Koester's video corresponds very well to, and indeed helps clarify, Agamben's position, detaching the creaturely body from the ritualistic straitjacket of the forms of spectacle to which it has fallen subordinate-with the Western movie functioning here as a sort of paradigm. In Koester's re-working, the genre's formulaic gestures of violent interaction are negated-the performers never touch the revolvers they wear, despite their obsessive miming of the gestures of aiming, shooting etc.-and through 'jerks and involuntary movements' (like Agamben's 'ataxia, tics and dystonia'), the cowboys find a route to a gesturality freed, rather than fixed, by the moving image.

Conversely, it is clear that the narrative control exerted by the Western genre as such is unlikely to leave any of the gestures it captures untouched. This is a point understood even by those commentators most sympathetic to the aesthetic potential of the genre. As Jane Tompkins writes in her superb book, West of Everything, 'There is never a moment when you aren't being programmed to believe, act, or feel a certain way' $(1992,210)$. Greil Marcus, in an essay called 'Cowboys and Germans', finds himself asking: 'in what sense is a mystification, that is the standard 
heroic Western image, free?' (1995a, 100). And, of course, this control is not just a matter of a narrative logic constraining gesturality, but is also ideologically driven. The Western unrolls against the horizon of Manifest Destiny, an ideology of White European-American entitlement and power with scant regard for ethical or aesthetic abstractions-the mantle of which, as Marcus says, John Wayne 'wears easily, happy to represent America to the world' (1995b, 209). Indeed, the very notion of destiny is described by Agamben as antithetical to what he means by ethics:

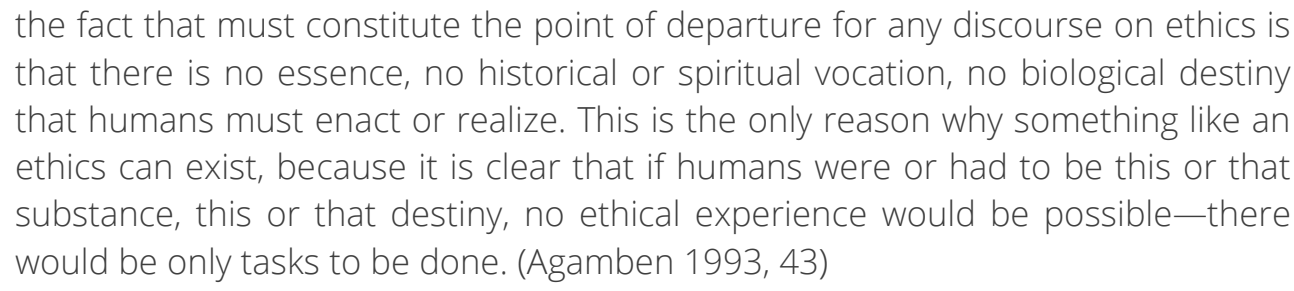

For Agamben, destiny and meaningfully human gestures are mutually exclusive: 'For human beings who have lost every sense of naturalness, each single gesture becomes a destiny' (Agamben 2000, 52).

One might expect a narrative concern with destiny to seep into every frame of the Western, leaving no residual space-in Agamben's terms-for gestures to breathe. In what follows I wish to argue that such a reading would be too narrow.

\section{The Ethics of Gesture and the Medium of Cinema}

I take from what Agamben says in 'Notes on Gesture' and elsewhere that cinema in its technological constitution captures and cuts up human movements, and in doing so can release the dynamic of gesture from the captivity of images (thus, in a Benjaminian way, mounting resistance from within technology to the general deforming application of technology). ${ }^{2}$ This potential is intrinsic to the medium of cinema, and therefore presumably observable in any cinematic instance, including Western films-even if Agamben would prefer Beckett, Debord, or Godard.

Although perhaps not straightforwardly definable in Agamben's terms, there is a prominent example of gesturality in the individual Western movie usually regarded as the greatest of them all, John Ford's The Searchers (1956). This is the climactic moment near the end, when the John Wayne character (Ethan Edwards) whom the audience has cause to fear is about to kill his niece Debbie, lifts her into the air instead. Now, of course, this moment is integrated into a narrative (and has words attached: 'Let's go home, Debbie'), but it is a narrative that is astonishingly problematic in relation to Marcus's 'standard heroic Western image' (1995a, 100). Behind a familiar revenge schema there is an implication that Ethan is in the grip of an irrational racial hatred reaching so deep within him that he identifies with the Native American 'other' he hates. ${ }^{3}$ This is why he is thought likely to kill Debbie, abducted by Indians, when he finally catches up with her after years of searching: for him death is a better fate than miscegenation. 
However, as the philosopher Robert Pippin says in a remarkable analysis of The Searchers, the motivation of the John Wayne character is much more complex than this. Ethan never articulates his racism and its interpretation depends upon 'many unknowns intimated visually, demanding some pursuit of purely visual intelligibility' $(2010,117) .{ }^{4}$ Of these, the culmination is the gesture at the end:

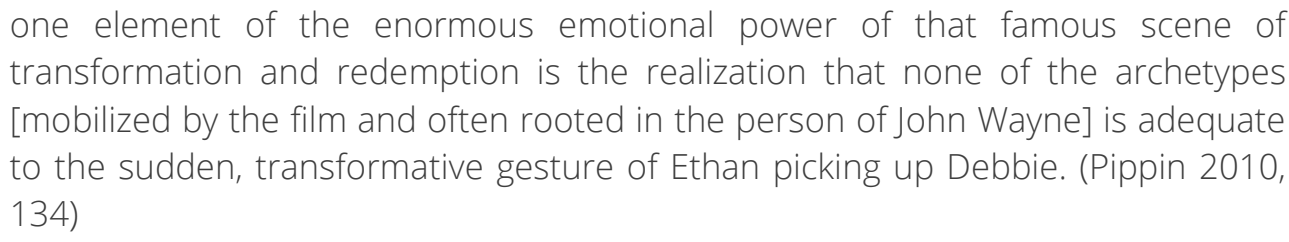

In another gesture, possibly even less integrated within narrative, Ethan's feelings regarding what subsequently turns out to have been the discovery of the body of Debbie's sister is expressed only by a mute but violent digging into the earth with a knife. The gesture has no instrumental or effective narrative function, although it recalls both sexual violence and the digging that has just served off-screen to bury the violated body. If it is a gesture to convey the opaque ethical confusion which has Ethan in its grip, his later action is obviously positive within the ethical narrative of the film.

And this positive turn is definitionally gestural. As Pippin and others have noted, it repeats and amplifies an ordinary social gesture from near the start of the film, in which Ethan, returning from a not-fully-explained post-civil-war sojourn in violent territory, had picked up Debbie as a child. These gestures suggest a moment of civilization in which two bodies touch, in which a stronger person forbears from violence while demonstrating superior strength, and the renunciation of potential for dominance. More profoundly, the final gesture acknowledges the genocidal stain in the construction of American identity-without, of course, being able to remove it.

Readers of film with a sharper gaze than my own have registered what might indeed be called an Agambenian importance of gesture in Westerns. Here is Alexander Horwarth, the Austrian film writer, on a film made by Ford ten years before The Searchers, My Darling Clementine:

\section{It's Sunday. Wyatt Earp [Henry Fonda] freshly groomed and shaven after his visit to the barber, strides slowly across the hotel veranda. He sits and balances on the chair, resting first one leg then the other against the veranda upright. This sublime moment contains the whole film: it is in a state of equilibrium [Er schwebt]. (Österreichisches Filmmuseum 2016; my translation)}

For Christian Petzold, the contemporary German filmmaker, Henry Fonda on the veranda is the epitome of the 'Schwebezustand', a 'state of hovering, floating or being poised', which, Petzold says, defines the ethically creative potential of all genres in cinema, generating for the filmmaker the very possibility of significant narrative: 'as long as there is this kind of balance, one can tell a story, one can make a film' (cited in Fisher 2013,155). The consciousness of potential that inheres in the generic Schwebezustand, brought about by gestural performance in My Darling Clementine, 
epitomises gesturality as such as a phenomenon of potentiality and suspension. What makes the particular genre of the Western movie at once aesthetically and ethically interesting is that this Schwebezustand clearly has to do with the moment of potential in US foundation myths-as is clear from the linkage of the veranda gesture with the visual drama following it. Wyatt Earp and Clementine Carter (Cathy Downs) walk from the veranda and join the townsfolk in a dance on the site of construction of a church, Monument Valley in the background, beneath the flag of the young United States. This is the Schwebezustand of the New World. As Gilberto Perez puts it, this halfcompleted church at the edge of the desert is a place 'where Wyatt Earp will forever dance with Clementine' $(1998,241)$.

In their equilibrium and sense of suspended potentiality, these gestures point toward that quality which characterises the best Westerns: that they are not ideologically rigid. Pippin, whose interest is in the political-philosophical implications of the Westerns of Ford and Howard Hawks, writes of the celebrated passage from My Darling Clementine on which we have just quoted Horwarth, Petzold and Perez: 'the civil societies at issue in such Westerns are "open and unfinished", and so any so-called nostalgia is for a time when the possibilities were open, not for any prefounding fixed way of cowboy life' $(2010,143)$. While the ethical-gestural content of these Westerns does not point forward to an as-yet-unknowable 'coming' community, the genre does concern what Perez, defining Ford's political viewpoint, calls 'a past that looked forward to a future' (241). There is a balance between what Agamben might describe as this gestural capture of ethical potentiality and what he disparaged above as 'tasks to be done' (Agamben 1993, 43). In the Western's retrospective view of a sense of a future, we are at a point upon which the shadow of the realisation has begun to fall that the sheer abundance of the new continent can never be perfectly converted into an actual political order. ${ }^{5}$

\section{‘The Weary Gunfighter’ and the Ethics of Gesture}

The essence of this ethical Schwebezustand is distilled in a particular subgenre of the Western. This is the subgenre of what David Foster Wallace (via his protagonist, Hal) summarises as 'the seductive formulae of violent payback' in Infinite Jest:

\footnotetext{
i.e. the cathartic bloodbath, i.e. the hero trying with every will-fiber to eschew the generic world of the stick and fist and but driven by unjust circumstances back to the violence again, to the cathartic final bloodbath the audience is brought to applaud instead of mourn. $(1996,704)$
}

Politically the 'weary gunfighter' motif reflects a moment at which the US is 'nearly an ordinary European country and no longer the place of promise' (Pippin 2010, 143). The figure is that of the killer who wishes to become bound by the restraints of civilization, but finds that that civilization cannot exist without his violence. In a passing allusion to Carl Schmitt and Agamben, Pippin says: 'a state of exception always looms' (145), one which will require the killer to kill again, and thus be excluded from civilized order after all; instead, he rides off into the sunset, alone, except for his horse. The two classical examples of this plot model to which I wish to draw attention are Shane 
(George Stevens, 1952) and Unforgiven (Clint Eastwood, 1992). Like The Searchers and My Darling Clementine, they are among the most well-known Westerns of all: the American Film Institute's third and fourth 'best Western' of all time respectively (The Searchers heads that particular list).

To take Shane first: the titular hero (Alan Ladd) arrives, from the endless landscape that provides the margin or penumbra of every Western plot, at a homestead containing a family called Starrett (father, mother, son). His past as a killer is established in various ways, but so is his readiness to help Joe Starrett with the struggle to make this individualist project work. There is a cattle man, Ryker, whose agricultural business strategy requires the whole range unfenced, and who therefore seeks to be rid of the fence-building Starretts and other homesteaders like them. He eventually hires a gunfighter (Jack Palance) to make good what he regards as his rightful claim by force. At this, reluctantly, and to prevent Starrett from suicidally confronting the killer himself, Shane takes his place and kills the Palance character and various others who get in the way. He then rides off back into the landscape, bonded only with his horse, and deaf to young Joey who entreats him to stay: 'Joey, there's no living with a killer...'.

The major part of the action of the film therefore takes place in what Agamben would call the 'zone of indistinction' between the aspirations of the Starrett family-impeccable in the ethical terms of the narrative (their name comes out as 'Start' in the dialogue, as if to suggest the foundation of a moral order)-and the need for murder outside the law in order to make their realisation possible. Somebody says at one point, in a memorable phrase, 'The law is three days' ride from here'. (There is an interesting contrast here with the line 'I AM the law' spoken by Wade Hatton [Errol Flynn] in the Flynn vehicle Dodge City [1939], which is clearly not ironical, and attests to the greater depth and subtlety of the more self-conscious, pure 'myth' of the best Westerns [see Bazin 1971, 152].) The actual shape and import of the narrative is as follows: once Shane has actually disclosed the state of emergency that dwells within the modern political order, he has to disappear, or, more precisely, to become an abstraction. His disappearance allows the law to enter and appear to fill the space that he must vacate. (This whole problematic is brilliantly explored in another Ford Western, The Man Who Shot Liberty Valance [1962].) Young Joey Starrett, who has represented the viewer throughout, embodies the benefit to the viewer and by extension civil society of the sacrifice made by Shane: 'Tell your mother there are no more guns in the valley... you go home to your mother and father and grow up to be strong ' $n$ ' straight...'.

But the film itself is not the disappearance into abstraction; it is in fact a series of gestural performances that flourish before the necessity of abstraction makes good its claim. Consider the first performance of Shane's readiness to help the Starrett family. Without saying a word, he gets up from the dinner table, goes outside the cabin and starts attacking a huge tree stump with an axe. At length, also without comment, Joe joins him and the two men are shown working together. The actual task they undertake is curiously indeterminate: they are getting rid of the remains of an enormous tree. They are neither felling it (it's already gone), nor uprooting it (there's no need), just levelling the ground. At a later point, the 'suspended', hovering, gunfighter gives in to Joey's pleading to teach him how to shoot. Shane impresses upon the boy that a gun is just a tool. But, of course, when Shane uses his gun in earnest, he is banished from the field in which tools have 
their rightful place. This 'telos' is fatal. In contrast, the stump chopping has a less clear outcome: what it captures and exposes by means of the editing is two potentially lethal weapons used as tools in a performance that bonds two men in labour.

About halfway through the film, there is a conversation between Ryker and Starrett about the rights and wrongs of their claims to the land and forms of livelihood. Ryker speaks on behalf of Manifest Destiny (i.e. big business) while Starrett presses the legal rights of the individual. This much is an explicit US political debate between commercial interests on one side and government-protected rights on the other. But the cinematic passage is a counterpoint that intersperses shots of the interlocutors and images of their respective enforcers, who circle round each other in a kind of choreography of menace: what is manifest here is the shadow of violence cast by the rational argument. And, clearly, the underpinning of potential violence is not just on the side of the ruthless rancher.

If such moments of gestural ethics contain an Agambenian kernel, they in their turn are clearly contained within the more mystifying ethical narrative (to use Marcus's adjective) in which the mutual dependence of violence and order is hidden within the abstraction of the law. In contrast, Unforgiven is a demystification of this untroubled confidence in the law, and it achieves this by exploiting (but, as we shall claim, not subverting) the genre that Shane exemplifies so purely.

Clint Eastwood, who plays the lead in Unforgiven, which he also produced and directed, himself carries a specific significance in terms of the history of the Western genre from Shane to the Spaghetti Western. If in Shane the gunfighter rides off into the sublime landscape, in the Spaghetti Western he emerges from nowhere, as at the beginning of $A$ Fistful of Dollars (Sergio Leone, 1964), minus any name, shame or scruple. In Unforgiven, this nameless, metaphysical instance is relocated in an 'ethical vision'. ${ }^{6}$ At some point before the story begins, the Eastwood character, Will Munny seems to have achieved the status of penniless but honest homesteader desired by Shane, but denied to him. The credit sequence pictures a figure silhouetted by the twilight of morning (or evening) digging a grave on a horizon empty of anything but a small cabin and a tree. It records visually the fusion of homesteader and killer (the axe imperceptibly becomes a spade ${ }^{7}$ ), but also the end of that dream. On the left-hand side of the screen text scrolls down, contextualising the action-and music ${ }^{8}$-already attracting our visual pleasure, in cold, judgemental prose:

\section{She was a comely young woman and not without prospects. Therefore it was heartbreaking to her mother that she would enter into marriage with William Munny, a known thief and murderer, a man of notoriously vicious and intemperate disposition.}

\section{When she died, it was not at his hands as her mother might have expected, but of smallpox. That was 1878.}

We move straight into the originating event of the plot, now set not in the nuclear/holy family of Shane, but in a frontier brothel. A cowboy slashes the face of a prostitute (Delilah Fitzgerald, played by Anna Levine/Thomson) who has mocked the size of his membrum virile. Unsatisfied with the 
measures taken by the law (in the person of Gene Hackman's Marshall, Little Bill), the sex workers club together and hire Munny to come out of retirement and kill the offenders. The murders are accomplished, though barely competently, by Munny and two associates. However, when one of them, Ned Logan (Morgan Freeman), is caught, publicly tortured and executed by Little Bill in a procedure of savage law enforcement, Munny reverts to his killer persona (the moment of disinhibition is the moment he takes his first slug of whisky in ten years), and kills everybody in a climax very like that of Shane-even down to the mise-en-scène, camera angles and menacing jangling of spurs-an ending that, as Vaux writes, 'activates the film's suppressed genre elements' (71).

The film is characterized by gestural moments which demystify the gunfighter as homesteader. The interaction of cattle, pigs, deer, the dog and humans at the beginning of Shane beautifully orchestrates the arrival of the hero. When we are introduced to Munny, by contrast, he is shown in uncomfortable low-angle close-up scrambling in the mud with his pigs, unable to keep upright. As if to emphasize the point, the self-glorifying 'Schofield Kid', who, it will transpire, has come to enlist Munny in the justice/revenge action of the frontier sex workers, articulates off-screen what the audience is thinking: 'you don't look like no rootin' tootin' sonovabitch assassin'. Shane emerges into his story on horseback, of course. Tompkins writes: 'More than any other single element in the genre, [horses] symbolize the desire to recuperate some lost connection to life' $(1992,94)$. In Unforgiven, this symbolization is intentionally blocked. When Munny attempts to mount his horse he falls off haplessly (twice) in a passage lasting almost a minute. A similar device is used to show how hard it is in reality to shoot small objects off fence rails using a revolver.

In these and many more moments-indeed, practically the whole development of the plot-the ethical point of the narrative is explicit from what Sara Anson Vaux calls the 'suppression' of the genre (2012). That is to say that what emerges in the suspended space between the passionate desire for justice and the ensuing bloodbath is the creaturely reality of suffering; the insistence of the body; how hard it is in fact morally to kill, and how brutal and undignified in practice; how unreliable firearms are as tools; how easily violence overshoots the requirements of justice; and so on. All this is clear. What is less clear is the role of the shootout with which the plot of Unforgiven, like that of Shane, culminates. Its function (and our pleasure in it) in the latter is clear enough. Little Joey, who relishes Shane's competence and mimes our own consumption of it throughout the film, must also accept his loss-the final words are Joey's 'Shane, come back!' The implication is that the viewer, too, having been entertained by the murders, can now grow up to be strong and straight and so on, having paid the price of renunciation.

Joey's equivalent in Unforgiven as our surrogate consumer/commodifier of violence is the character of W.W. Beauchamp, the writer. We cannot ignore his surrogacy on our behalf, but to identify with him is shameful since he is both a physical coward-he graphically and realistically wets himself when actual violence threatens-and the agent of commercial exploitation of killing as entertainment. I have long reflected upon my bad conscience at enjoying the concluding bloodbath, an enjoyment that I take to be required by the aesthetic and thematic structure of the 
film. My conclusion is that Eastwood and David Webb Peoples, who wrote the screenplay, make explicit and leave unresolved in a meaningful way what Shane disavows and resolves.

The return of the hyper-competent killer, after so much assurance that such persons do not exist in reality, introduces what can only be described as a metaphysical element. Earlier in the film English Bob (Richard Harris) had explained, a propos of the contemporaneous wounding of President Garfield, why it is that you can assassinate an elected president, but not a sovereign monarch: 'If you were to point a pistol at a king or queen your hands would shake at the sight of royalty and would cause you to dismiss all thought of bloodshed, you would stand how shall I put it, in awe, but a president, well, I mean, why not shoot a president...?'9 At the end of the film, Munny inspires a similar sort of sovereign awe. After he has completed his massacre he leaves the saloon, and anybody is in a position to shoot him down. But nobody does. He remains invincible, but not because of any respect derived from civil structures of authority, but by the awe inspired by the certainty of pitiless violence hidden within it. We are in the state of exception. It is pitch black and pouring, you can't see a thing clearly except Munny's white horse. 'Alright', he says, in a strikingly resigned, impersonal or disinterested tone, I' $m$ coming out, any man I see out there, I'm going to kill him [...], anyone takes a shot at me I'm going to kill him, kill his wife, burn his damn house down....' The logic of genre allows Eastwood and Peoples to confront the violence which Little Bill has striven to put to use in the establishment of justice, albeit with an undertow of sadism, with the reality of violence, which is that it is in a sense absolute. The state of exception that the killer embodies cannot be sublated. The means cannot be contained within the ends.

I would argue that our pleasure-the visceral reality of which is difficult to deny without negating the dramatic and aesthetic shape of the whole work-although we might be ashamed of it, is removed from the sphere of entertainment. It is unforgiven: our shame. ${ }^{10}$ But the climax is also removed from the sphere of conventional ethics ${ }^{11}$ in which, according to Agamben, 'the false alternative between ends and means [...] paralyzes morality' $(2000,56)$. After Munny has ejected the fawning Beauchamp (thereby possibly taking us beyond our shame), this dialogue ensues between the mortally wounded Little Bill on the bar-room floor and Munny towering above him:

Little Bill: I don't deserve this. To die like this. I was building a house.

Munny: Deserve's got nothing to do with it.

Little Bill: I'll see you in hell, William Munny.

Burst of storm sound; sounds of cocking of Spencer rifle at distance of a few feet.

Munny: Yeah

Little Bill takes one last breath.

Gunshot. 
Little Bill's last breath, perhaps, is the gesture, unstressed, but inseparable from the cinematic medium (which alone among media will capture and preserve such a point of undifferentiated life), that comes closest to that 'something like an ethics' beyond ethics of which Agamben speaks. ${ }^{12}$

\title{
The Ethics of Genre
}

In his remarks on the vicissitudes and significance of gesture, Agamben concludes by claiming that the 'appearance' or 'exposure' of mediality (such as he discerns in authentic gesture) is the condition of human community and opens an ethical space $(2000,58-9)$. Perhaps we are now in a position to make sense of these words in relation to the genre of the Western movie. The relevance here of Wallace's Infinite Jest goes beyond simply providing the term and definition for the 'violent payback' narrative arc. In referring to that topos, Wallace's character Hal was in fact mounting a critique of his father's avant-garde film-making tendencies in relation to genre:

\begin{abstract}
Hal's critical take on the film is that Himself [how Hal refers to his father], at certain dark points when abstract theory-issues seemed to provide an escape from the far more wrenching creative work of making humanly true or entertaining cartridges [a fictional futuristic format for the distribution of films], had made films in certain commercial-type genre modes that so grotesquely exaggerated the formulaic schticks of the genres that they became ironic metacinematic parodies on the genres. $(1996,703)$
\end{abstract}

Hal's disapproval is clear from the words that follow: "sub/inversions of the genres," cognoscenti taken in were wont to call them'. Wallace's point, as I understand it, is that genres are not ultimately sub- or invertible, pace Joachim Koester. This crucially serious moral position is, I would argue, driven home in the next few pages of Wallace's novel.

Throughout Infinite Jest, the demands placed on a recovering addict by collectives such as Alcoholics or Narcotics Anonymous serve to represent the extraordinary effort demanded of an individual if he or she is to recover moral agency in contemporary reality (what Guy Debord, to whose memory Agamben's Means without End is dedicated, characterised as 'the society of the spectacle'):

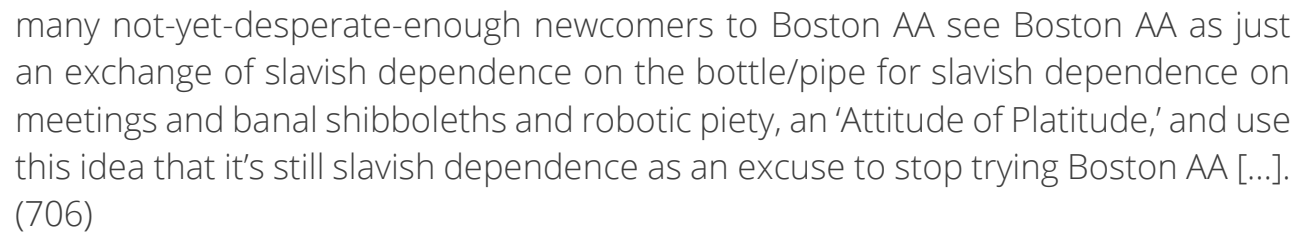

This false assumption of freedom provides, I suggest, an analogy with the erroneous idea that genre can be transcended at will. In Agamben's terms, it is to wrongly dismiss mediality as 'platitude'. The return to dependence that inevitably ensues in the case of Wallace's smug substance abusers, we read, beats 'them into such a double-bound desperation that they finally 
come back in with their faces hanging off their skulls and beg to be told just what platitudes to shout, and how high to adjust their vacant grins' (706).

Against this powerful depiction of the reality of addiction and the rigours that alone can overcome it, the novel provides an image of positive resistance to dependency that is linked to the generic 'violent payback' pattern. This occurs through one of the most persistent leitmotif characters, Don Gately, who embodies the problematic of addiction and its implications for an ethics of modernity. He has submitted to the proper discipline of AA and become rehabilitated, but, in a climactic moment of the novel, he throws off all restraint in order heroically to protect the inmates of the centre for recovering addicts, in which he now has a role as custodian, against the threat of extreme violence. This is a bloodbath if ever there was one, and it is hard to imagine that Wallace, who thought extremely highly of Unforgiven and David Webb Peoples (see Rose 1997), didn't wish us to make the connection, so effectively does he bring us 'to applaud instead of mourn' this relapse on Gateley's part into murderous criminality. Where Hal's father, in his darkest most 'theoretical' and uncreative moments, seeks to parody and subvert, Wallace acknowledges the nontranscendable nature of 'the generic world of stick and fist and (sic)' by himself employing the cliché or platitude offered by the genre. But his hero, Don Gately, does not ride off into the sunset like Shane, leaving the ambivalence of the law in suspension. This much he has in common with Will Munny. Instead he displays a moral heroism commensurate with his physical prowess, by refusing to accept the palliation of drugs (and thus an inevitable relapse into dependence) in the many hundred-page recovery process from the terrible wounds he has received in 'performing the platitude'. Wallace's enormous novel, which directs much of its moral and aesthetic effort towards tracing the convergences and divergences between literature and film, can go further than Eastwood and Peoples in probing the limits of genre. But through the novel's structural use of the violent payback motif, it nevertheless maintains the same position as they do: that it is not philosophically responsible to claim to transcend it.

Where Petzold, cited earlier, attested to the potentiality of genre ('...as long as there is this kind of balance, one can tell a story, one can make a film'), Wallace amplifies the ethical dimension of Petzold's point. By blocking the delusion that there is an 'outside' to human discourses from which some help or redemption might be expected (of which delusion the 'attitude of platitude' or avantgarde disdain for genre patterns are representatives) Wallace focuses the formidable ethical demands posed by the reality of what Agamben would know as Debord's spectacular modernity. Exposing the resistance of 'genres' to meaningful sub- or inversion can therefore have the same function as 'gesture' does in relation to 'language' for Agamben, who writes:

if we understand the 'word' as the means of communication, then to show a word does not mean to have at one's disposal a higher level (a metalanguage, itself incommunicable within the first level), starting from which we could make that word an object of communication; it means, rather, to expose the word in its own mediality, in its own being a means, without any transcendence. The gesture is, in this sense, communication of a communicability. It has precisely nothing to say because what it shows is the being-in-language of human beings as pure mediality. $(2000,58)$ 
The fact and display of mediality, whether in the case of words, gestures or genre, rather than facilitating transcendence, can and should be acknowledged as the ground for genuine ethical experience. It bears witness to the 'being-in-a-medium of human beings' and it therefore 'opens the ethical dimension for them' (57). This is a dimension not determined by an overriding destiny or direction-hence the great Westerns suspend the 'end' of Manifest Destiny-but a space of human responsibility, in which means are not instrumentalised by ends, nor are they ends in themselves (see Agamben 2000, 57). The political aporia generated by the perpetual noncoincidence of hope and possibility is one that must be 'endured and supported' rather than sublated or concealed within closed logics of production or action. ${ }^{13}$

\section{Notes}

${ }^{1}$ Koester's installation, In the Face of Overwhelming Forces, was mounted at the Camden Arts Centre in London from 28 January to 26 March 2017.

2 For an overview of Agamben's view of cinema see Grønstad and Gustafsson (2014).

${ }^{3}$ For Ethan's complicated identification with the hated 'other', see Pippin (2010), especially 112.

${ }^{4}$ On the same page (117), Pippin draws attention to the enigma of this moment: 'What is the meaning of Ethan's famous gesture at the end, raising Debbie once again above his head?'

5 The United States of America did indeed once seem to promise a 'coming community' in which scarcity, injustice and inequality would disappear. Hannah Arendt, for whom the American, rather than the French, Revolution was the superior but sadly neglected, historiographical example, quotes John Adams: 'I always consider the settlement of America as the opening of a grand scheme and design in Providence for the illumination of the ignorant and the emancipation of the slavish part of mankind all over the earth' (cit. Arendt 2006, 13). In the context of the ambivalence of 'destiny' in US culture it is instructive to glance at the way Agamben and others make use of that iconic US writer, Herman Melville. While Agamben sees a prolepsis of a kind of 'anti-destiny' in Bartleby's refusal of the deformations of modernity, Bonnie Honig draws attention to Melville's alternative model, of a possible cooperative community, in Ishmael and the crew of the Pequod $(2016,158)$. This affords a glimpse of a perpetual tension between political hope and political possibility.

${ }^{6}$ I take the phrase, but not my argument, from Sara Anson Vaux's, The Ethical Vision of Clint Eastwood (2012). Vaux takes a conventional (fundamentally theological) line about the subversion of genre to which, as will become clear, I cannot give assent. For David Foster Wallace, Unforgiven is 'not a Western at all', but 'a moral drama [...] It's Henry James, basically' (Rose 1997).

7 I am grateful to Rebecca Schneider for pointing out this subtle transition.

${ }^{8}$ For a thoughtful and persuasive analysis of Eastwood's use of music in this opening sequence and elsewhere, as opposed to that of John Ford, for instance, see Vaux (2012), 224-5.

${ }^{9}$ Perhaps the assassination of Archduke Franz Ferdinand was to mark the definitive historical end of this kind of attitude.

10 The moment of shame that dwells both within our pleasure at 'violent payback' and in the creaturely necessity of dwelling between hope and possibility, brilliantly exposed in Unforgiven, is perhaps also present, but hidden by the mask of one consonant, in the title of our other example of this subgenre.

11 The reconstructed Munny is full of platitudes about 'deserving' and 'wickedness' - in other words he is portrayed 
with psychological realism. However, at the end of the film, he is not a psychologically realistic figure. It is not aesthetically legitimate to link the possible shallowness or conventionality of his moral position with his generic reversion to type (i.e, say it is just another weakness).

12 It is notable that after the 'happy dance' in Koester's The Place of Dead Roads, referred to above, there is a fifteen second close-up of one of the exhausted performer's faces, just breathing.

13 'What characterizes gesture is that in it nothing is being produced or acted, but rather something is being endured and supported' (Agamben 2000, 56). Eastwood himself, in publicly coming out in favour of Donald Trump, betrayed this political ethic. For what must deeply distress the civilised western individual about the assumption of power of the Trump interest is the return of an ideology of what was referred to above as a 'White EuropeanAmerican entitlement and power with scant regard for ethical or aesthetic abstractions'. Rhetorically at least, this interest disregards the disparity between hope and possibility, plumping instead for a closed logic of action in terms of which there is nothing problematic about the direct violent suppression of those opposed to itself, proclaiming (like Errol Flynn) 'I AM the Law'.

\section{Works Cited}

Agamben, Giorgio. 1993. The Coming Community. Translated by Michael Hardt. Minneapolis: University of Minnesota Press.

_-_ 2000. 'Notes on Gesture'. In Means without End: Notes on Politics, translated by Vincenzo Binetti and Cesare Casarino, 49-59. Minneapolis: University of Minnesota Press.

Arendt, Hannah. 2006. On Revolution. London: Penguin.

Bazin, André. 1971. 'The Western, or the American Film par excellence'. In What Is Cinema?, 2:140-48. Berkeley: University of California Press.

Birmingham, Peg. 2011. 'Agamben on Violence, Language, and Human Rights'. In Philosophy and the Return of Violence: Studies from the Widening Gyre, edited by Nathan Eckstrand and Christopher S. Yates, 124-34. London: Continuum.

Fisher, Jaimey. 2013. Christian Petzold. Chicago: University of Illinois Press.

Grønstad, Asbjørn, and Henrik Gustafsson. 2014. 'Introduction: Giorgio Agamben and the Shape of Cinema to Come'. In Cinema and Agamben: Ethics, Biopolitics and the Moving Image, edited by Asbjørn Grønstad and Henrik Gustafsson. New York: Bloomsbury.

Honig, Bonnie. 2016. 'Charged: Debt, Power, and the Politics of the Flesh in Shakespeare's Merchant, Melville's Moby Dick, and Eric Santner's The Weight of All Flesh'. In The Weight of All Flesh: On the Subject-Matter of Political Economy, by Eric L. Santner, edited by Kevis Goodman, 131-82. Oxford: Oxford University Press.

Koester, Joachim. 2017. 'The Place of Dead Roads'. Wall-mounted description at Camden Arts Centre, London, where the video installation was exhibited from 28 January to 26 March 2017.

Marcus, Greil. 1995a. 'Cowboy Boots and Germans'. In The Dustbin of History, 103-110. Cambridge, MA: Harvard University Press.

1995b. 'John Wayne Listening'. In The Dustbin of History, 209-215. Cambridge, MA: Harvard University Press.

Österreichisches Filmmuseum. 2016. "My Darling Clementine." Accessed 1 November 2016. https://www.filmmuseum.at/jart/prj3/filmmuseum/main.jart?j-jurl=/kinoprogramm/produktion\&veranstaltungen_id=1110\&ss1=y 
Perez, Gilberto. 1998. The Material Ghost: Films and Their Medium. Baltimore: Johns Hopkins University Press.

Pippin, Robert B. 2010. Hollywood Westerns and American Myth: The Importance of Howard Hawks and John Ford for Political Philosophy. New Haven: Yale University Press.

Rose, Charlie. 1997. "Interview with David Foster Wallace. The Charlie Rose Show March 27 1997." Accessed 22 November 2015. http://www.smallbytes.net/ bobkat/rose.html

Tompkins, Jane. 1992. West of Everything: The Inner Life of Westerns. Oxford: Oxford University Press.

Vaux, Sara Anson. 2012. The Ethical Vision of Clint Eastwood. Grand Rapids: Eerdmans.

Wallace, David Foster. 1996. Infinite Jest. New York: Little, Brown and Company.

\section{Biography}

Michael Minden was until 2016 Reader in German Literature and Culture at the University of Cambridge and is Emeritus Fellow of Jesus College, Cambridge. He has written on a wide range of topics in German literature, thought and film, including books on Arno Schmidt and the Bildungsroman. His most recent book is Modern German Literature (Polity, 2011), since the publication of which he has written on Christa Wolf, Günter Grass, Rainer Maria Rilke, Ingeborg Bachmann and Ruth Klüger, all more or less under the broad heading of 'Literature and Experience'.

(c) 2017 Michael Minden

cc) (i) Except where otherwise noted, this work is licensed under a Creative Commons Attribution-

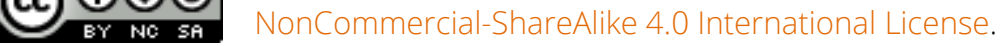

